\title{
CGA wt Allele
}

National Cancer Institute

\section{Source}

National Cancer Institute. CGA wt Allele. NCI Thesaurus. Code C129841.

Human CGA wild-type allele is located in the vicinity of $6 q 14.3$ and is approximately $10 \mathrm{~kb}$ in length. This allele, which encodes glycoprotein hormones alpha chain protein, is involved in protein hormone-dependent signaling. 